\title{
Effect of rumen-protected choline supplementation on liver and adipose gene expression during the transition period in dairy cattle
}

\author{
R. M. A. Goselink, ${ }^{* 1}$ J. van Baal, ${ }^{*}$ H. C. A. Widjaja, ${ }^{*}$ R. A. Dekker, ${ }^{*}$ R. L. G. Zom, ${ }^{*}$ M. J. de Veth, $\dagger$ \\ and A. M. van Vuuren* \\ *Wageningen UR Livestock Research, PO Box 65, 8200 AB Lelystad, the Netherlands \\ †Balchem Corporation, Animal Nutrition and Health, New Hampton, NY 10958
}

\begin{abstract}
We previously reported that supplementation of rumen-protected choline (RPC) reduces the hepatic triacylglycerol concentration in periparturient dairy cows during early lactation. Here, we investigated the effect of RPC on the transcript levels of lipid metabolism-related genes in liver and adipose tissue biopsies, taken at wk $-3,1,3$, and 6 after calving, to elucidate the mechanisms underlying this RPC-induced reduction of hepatic lipidosis. Sixteen multiparous cows were blocked into 8 pairs and randomly allocated to either 1 of 2 treatments, with or without RPC. Treatments were applied from 3 wk before to 6 wk after calving. Both groups received a basal diet and concentrate mixture. One group received RPC supplementation, resulting in an intake of $14.4 \mathrm{~g}$ of choline per day, whereas controls received an isoenergetic mixture of palm oil and additional soybean meal. Liver and adipose tissue biopsies were taken at wk $-3,1,3$, and 6 to determine the mRNA abundance of 18 key genes involved in liver and adipose tissue lipid and energy metabolism. Milk samples were collected in wk 1, 2, 3, and 6 postpartum for analysis of milk fatty acid (FA) composition. The RPC-induced reduction in hepatic lipidosis could not be attributed to altered lipolysis in adipose tissue, as no treatment effect was observed on the expression of peroxisome proliferator-activated receptor $\gamma$, lipoprotein lipase, or FA synthase in adipose tissue, or on the milk FA composition. Rumen-protected choline supplementation increased the expression of FA transport protein 5 and carnitine transporter SLC22A5 in the liver, suggesting an increase in the capacity of FA uptake and intracellular transport, but no treatment effect was observed on carnitine palmitoyl transferase 1A, transporting long-chain FA into mitochondria. In the same organ, RPC appeared to promote apolipoprotein B-containing lipoprotein assembly, as shown
\end{abstract}

Received January 31, 2012.

Accepted September 30, 2012.

${ }^{1}$ Corresponding author: roselinde.goselink@wur.nl by elevated microsomal triglyceride transfer protein expression and apolipoprotein B100 expression. Cows supplemented with RPC displayed elevated levels of glucose transporter $2 \mathrm{mRNA}$ and a reduced peak in pyruvate carboxylase mRNA immediately after calving, showing that supplementation also resulted in improved carbohydrate metabolism. The results from this study suggest that RPC supplementation reduces liver triacylglycerol by improved FA processing and very-low-density lipoprotein synthesis, and RPC also benefits hepatic carbohydrate metabolism.

Key words: dairy cow, choline, fatty liver, gene expression

\section{INTRODUCTION}

The transition to lactation is supported by hormoneinduced adaptations in fat metabolism in all mammals, including dairy cows (Friggens et al., 2004). These homeorhetic processes are accompanied by an increased release of FA from adipose tissue, elevating blood levels of NEFA. Furthermore, lipolysis is sustained during early lactation as long as energy intake cannot compensate for the increased energy demand of lactation (McNamara, 1991; Grummer, 2008). Aside from being utilized by the mammary gland, part of the circulatory NEFA are taken up by the liver, where they can be metabolized through 1 of 3 major pathways: (1) direct production of energy via oxidation of NEFA in mitochondria or peroxisomes, (2) production of ketone bodies (i.e., acetoacetate, acetone, and BHBA) through partial oxidation, or (3) reesterification into triacylglycerol (TAG), which can then either be sequestered in internal stores or be released into the circulation as TAG-rich, very-low-density lipoproteins (VLDL; Drackley et al., 2006; Grummer, 2008). In ruminants, however, VLDL secretion is relatively low, which predisposes the animals to hepatic lipidosis and ketosis (Kleppe et al., 1988).

Synthesis of VLDL requires TAG, phospholipids, cholesterol esters, microsomal triglyceride transfer protein (MTTP), and apolipoproteins such as apolipoprotein B100 (Bernabucci et al., 2004). Choline, a quasi- 
vitamin with various functions, is incorporated into phosphatidylcholine, the major phospholipid of VLDL. When phosphatidylcholine is limiting, choline supplementation may improve the rate of VLDL synthesis and thereby prevent excessive TAG accumulation in the liver (Grummer, 2008). In contrast to humans and rodents, choline availability in ruminants is hampered by the loss of dietary choline by extensive microbial degradation (Sharma and Erdman, 1989), which means that supplements should be industrially protected against ruminal degradation. Indeed, we and others have previously demonstrated that rumen-protected choline (RPC) supplementation to dairy cattle reduces fat accumulation in the liver (Cooke et al., 2007; Zom et al., 2011), increases milk production (Elek et al., 2008) and milk protein production (Zom et al., 2011). Yet, the underlying molecular mechanisms for the beneficial effects of RPC in periparturient dairy cattle are not fully understood.

In the present study, we propose a model for the action of RPC on FA processing by the bovine liver during early lactation, based on the temporal gene-expression profiles of 18 key energy metabolism-related enzymes in liver and adipose tissue, assessed by real-time quantitative PCR (qPCR) and the FA composition of milk to assess adipose mobilization. This model may be helpful in defining new strategies of RPC supplementation to reduce the incidence of hepatic lipidosis and ketosis in dairy cattle.

\section{MATERIALS AND METHODS}

\section{Animals and Treatments}

All experimental protocols and interventions were approved by the Ethical Committee on Animal Experiments of the Animal Sciences Group of Wageningen University and Research Centre (Lelystad, the Netherlands). The experiment was carried out between January 5, and April 26, 2009, as a complete randomized block designed structure comprising 16 HolsteinFriesian cows (7 second-parity, 5 third-parity, and 4 older cows), within a larger performance trial described by Zom et al. (2011). Cows were paired in 8 blocks on the basis of similarity in parity, expected date of calving and milk performance in the previous lactation (in order of priority).

Cows were housed in a cubicle shed and were kept in separate dry cow and lactating cow groups. Four weeks before the expected date of calving, cows were moved to the precalving group. On the day of calving, cows were separated from the dry cow group and housed in a straw-bedded calving pen. After calving, the cows were moved to the postcalving group. Cows were milked twice daily at 0600 and $1700 \mathrm{~h}$ in a milking parlor.

Cows within each block were randomly allocated to either the control $(\mathbf{C O N})$ or choline $(\mathbf{C H O L})$ treatment group. Cows in the CHOL group received daily $60 \mathrm{~g}$ of an RPC source (ReaShure; Balchem Corp., New Hampton, NY) that was mixed with $540 \mathrm{~g}$ of soybean meal. As ReaShure contained $24 \%$ choline, each CHOL cow received $14.4 \mathrm{~g}$ of choline per day. Cows in group CON did not receive any choline supplementation, but were supplemented with a mixture of soybean meal and palm oil (582 and $18 \mathrm{~g} / \mathrm{d}$, respectively) to supply equal protein, energy, and crude fat levels. The experimental treatments started 3 wk before the expected calving date (wk -3) and lasted until 6 wk after calving (wk 6).

\section{Diets and Feeding Management}

From 4 wk before calving until calving, cows received ad libitum the precalving feed mixture (Table 1) supplemented with a close-up compound concentrate. The daily concentrate allowance was increased gradually from zero at d 21 to $0.9 \mathrm{~kg}$ of $\mathrm{DM}$ on the expected day of calving.

After calving, cows received ad libitum the postcalving feed mixture (Table 1), supplemented with an early-lactation compound concentrate. The daily allowance of this concentrate was increased with $0.45 \mathrm{~kg}$ of $\mathrm{DM} / \mathrm{d}$ from $0.9 \mathrm{~kg}$ of $\mathrm{DM} / \mathrm{d}$ on d 0 (i.e., calving) up to $8.1 \mathrm{~kg}$ of DM/d on d17. The maximum level of concentrate was maintained from d 17 until the end of the experimental period at $\mathrm{d} 43$. Concentrate ingredients and chemical composition of all feeds are described by Zom et al. (2011).

The compound concentrates as well as the CHOL or CON supplement were fed individually using 3 transponder-controlled concentrate dispensers. The feed mixtures were supplied in feed weighing troughs with transponder-controlled access gates (Insentec BV, Marknesse, the Netherlands) which were continuously accessible for each cow, except during milking and when refusals were removed and fresh feed was supplied. Daily, between 1030 and 1100 h, feed refusals were removed from the troughs and a fresh feed mixture was supplied. To ensure ad libitum intake of the feed mixture, the refusal weight was at least $10 \%$ of the fresh weight at offer. The cows had unrestricted access to fresh drinking water.

\section{Tissue Sampling}

Liver and adipose tissue biopsies were taken on Mondays of wk -3 , just before the experimental treatment 
Table 1. Ingredients of the feed mixtures and amounts of supplement fed

\begin{tabular}{|c|c|c|c|c|}
\hline \multirow[b]{2}{*}{ Item } & \multicolumn{2}{|c|}{ Precalving treatment $^{1}$} & \multicolumn{2}{|c|}{ Postcalving treatment } \\
\hline & $\mathrm{CON}$ & CHOL & $\mathrm{CON}$ & CHOL \\
\hline \multicolumn{5}{|l|}{ Ingredients of feed mixture ( $\%$ of DM) } \\
\hline Wilted grass silage & 29.8 & 29.8 & 52.3 & 52.3 \\
\hline Corn silage & 29.6 & 29.6 & 34.7 & 34.7 \\
\hline Grass seed straw & & & 6.2 & 6.2 \\
\hline Wheat straw & 32.3 & 32.3 & & \\
\hline Soybean meal solvent extract & 7.0 & 7.0 & 3.1 & 3.1 \\
\hline Soybean meal formaldehyde treated & - & - & 3.0 & 3.0 \\
\hline Vitamin and mineral premix ${ }^{2}$ & 0.8 & 0.8 & 0.5 & 0.5 \\
\hline Magnesium oxide & 0.5 & 0.5 & - & - \\
\hline Salt & - & - & 0.2 & 0.2 \\
\hline \multicolumn{5}{|l|}{ Concentrate dispensers ( $\mathrm{kg} / \mathrm{cow}$ per day) } \\
\hline Soybean meal with palm oil & 0.6 & & 0.6 & \\
\hline Soybean meal with choline & & 0.6 & & 0.6 \\
\hline Prelactation compound feed & 1.0 & 1.0 & & \\
\hline Lactation compound feed & & & 9.0 & 9.0 \\
\hline
\end{tabular}

${ }^{1}$ Treatments: CON $=$ control group, supplemented with a mixture of soybean meal and palm oil (582 and 18 $\mathrm{g} / \mathrm{d}$, respectively); $\mathrm{CHOL}=$ choline treatment group that received daily $60 \mathrm{~g}$ of a rumen-protected choline source (ReaShure; Balchem Corp., New Hampton, NY) that was mixed with $540 \mathrm{~g}$ of soybean meal.

${ }^{2}$ Dry cow vitamin and mineral premix provided $10.8 \mathrm{mg}$ of $\mathrm{Cu}, 10 \mathrm{mg}$ of $\mathrm{Zn}, 12 \mathrm{mg}$ of $\mathrm{Mn}, 0.12 \mathrm{mg}$ of Co, 0.32 $\mathrm{mg}$ of I, $0.14 \mathrm{mg}$ of Se, 2,500 IU of vitamin A, $500 \mathrm{IU}$ of vitamin $\mathrm{D}_{3}$, and $40 \mathrm{IU}$ of vitamin $\mathrm{E}$ per kilogram of feed mixture DM. Lactating cow vitamin and mineral premix provided $6 \mathrm{mg}$ of $\mathrm{Cu}, 12.5 \mathrm{mg}$ of $\mathrm{Zn}, 15 \mathrm{mg}$ of $\mathrm{Mn}$, $0.09 \mathrm{mg}$ of $\mathrm{Co}, 0.6 \mathrm{mg}$ of I, $0.17 \mathrm{mg}$ of Se, 2,500 IU of vitamin A, $500 \mathrm{IU}$ of vitamin $\mathrm{D}_{3}$, and $7 \mathrm{IU}$ of vitamin E per kilogram of feed mixture DM.

was started, and on Mondays of wk 1, 3, and 6 postcalving. Liver tissue was harvested by percutaneous needle biopsy as described by Zom et al. (2011).

Subsequently, adipose tissue was sampled from the tail region between the ischium (pin bone) and coccygeal vertebrae. First the area was clipped, scrubbed with antiseptic solution, and disinfected. A local anesthetic was injected subcutaneously $(5 \mathrm{~mL}$ of lidocaineHCL 2\% with adrenaline; Eurovet Animal Health BV, Bladel, the Netherlands). An incision was made and 3 samples of approximately $5 \mathrm{~g}$ of adipose tissue were dissected. The incisions were sutured with staples and protected with a film dressing spray (Opsite; Smith \& Nephew, Hoofddorp, the Netherlands). All dissected liver and adipose tissue samples were immediately snap frozen in liquid nitrogen and stored at $-80^{\circ} \mathrm{C}$ until RNA extraction.

\section{$q P C R$}

For gene expression measurements, frozen samples of liver and adipose tissue were ground under liquid nitrogen and total RNA was isolated using TRIzol reagent (Invitrogen, Breda, the Netherlands), following the manufacturer's instructions. To eliminate DNA contamination, the isolated RNA was subjected to an on-column DNase treatment (NucleoSpin RNA II kit; Macherey-Nagel GmbH \& Co. KG, Düren, Germany). Reverse transcription of $1 \mathrm{mg}$ of total RNA was performed in a $20-\mu \mathrm{L}$ reaction using Superscript III reverse transcriptase (Invitrogen), deoxyribonucleotide triphosphate (dNTP; Roche Diagnostics Nederland BV, Almere, the Netherlands), and random hexamer primers (Roche Diagnostics Nederland BV) for $1 \mathrm{~h}$ at $50^{\circ} \mathrm{C}$ according to the manufacturer's protocol (Invitrogen). The primers used are presented in Table 2. Templates were amplified after a preincubation for $10 \mathrm{~min}$ at $95^{\circ} \mathrm{C}$, followed by amplification for 40 cycles $\left(10 \mathrm{~s}\right.$ at $95^{\circ} \mathrm{C}, 5$ $\mathrm{s}$ at $60^{\circ} \mathrm{C}$, and $5 \mathrm{~s}$ at $72^{\circ} \mathrm{C}$ ) on a 7500 Fast Real-Time PCR System (Applied Biosystems Deutschland GmbH, Darmstadt, Germany) by using the SensiMix SYBR Low-ROX kit (Bioline UK Ltd., London, UK). All reactions revealed a single product as determined by melting curve analysis. Quantitative mRNA measurement was performed by establishing a linear calibration curve using serial dilutions of cDNA for corresponding genes. We measured the transcript levels of the following key enzymes related to FA and energy metabolism in the liver: FA transport proteins (FATP) 2 and 5 (FATP2 and FATP5), FA-binding protein 1 (FABP1), glucose transporter 2 (GLUT2), carnitine palmitoyltransferase 1A (CPT1A), organic cation-carnitine transporter (SLC22A5), glycerol-3-phosphate O-acetyltransferase 1 (GPAT1), MTTP, apoprotein B100 (APOB100), peroxisome proliferator-activated receptors (PPAR) $\alpha$ and $\delta$ (PPAR $\alpha$ and PPAR $\delta)$, pyruvate carboxykinase (PC), pyruvate dehydrogenase kinase isotype 4 (PDK4), and mitochondrial as well as cytosolic phosphoenolpyruvate carboxykinase (PEPCK) $\mathrm{m}$ and $\mathrm{c}$ (PEPCK-m and PEPCK-c). In addition, the expres- 
Table 2. Sequences of the primers used for quantitative PCR in liver and adipose tissue

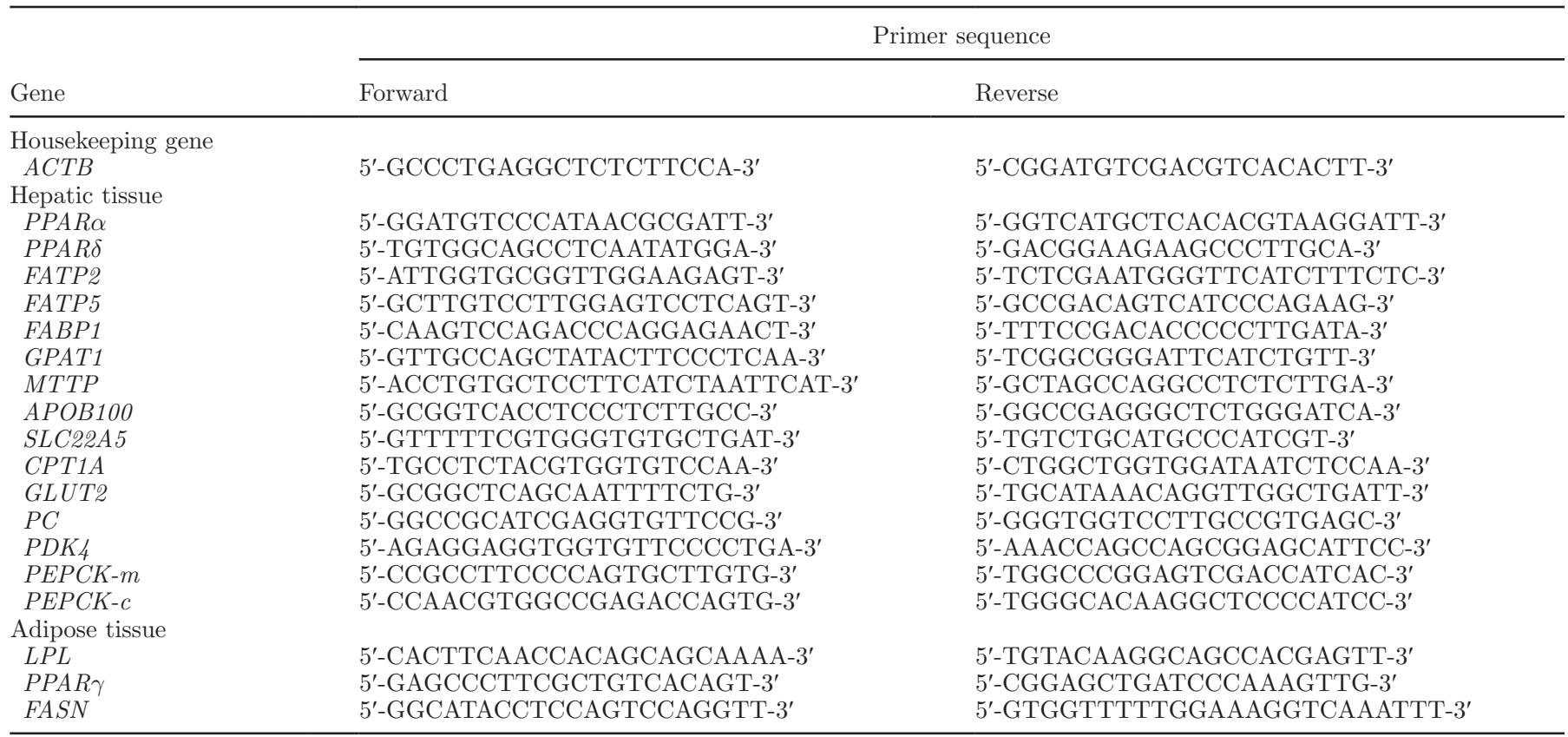

sion of 3 key enzymes was analyzed in adipose tissue: FA synthase (FASN), lipoprotein lipase (LPL), and PPAR $\gamma$. Gene expression of housekeeping genes $18 \mathrm{~S}$ ribosomal RNA and $\beta$-actin $(\boldsymbol{A} \boldsymbol{C T \boldsymbol { B }})$ were also analyzed as internal standard. Variation in $18 \mathrm{~S}$ ribosomal RNA expression was much higher than for $A C T B$ in the collected liver biopsies (unpublished results). Absolute expression levels of genes of interest were, therefore, normalized using their corresponding values of $A C T B$.

\section{Milk FA Composition}

For milk FA analysis, samples of each cow were collected during 2 a.m. milkings on consecutive days in wk 1, 2, 3, and 6 postpartum. Both a.m. milkings were pooled to 1 composite sample per cow per week. Milk samples were analyzed for FA composition as described previously by Mach et al. (2011).

\section{Statistical Analysis}

For $\mathrm{qPCR}$ results, the ratios between the absolute mRNA concentration of the relevant genes and housekeeping gene $A C T B$ were calculated at each time point (wk $-3,1,3$, and 6). For milk FA composition, individual FA levels were expressed relative to the total amount of FA in milk samples at each time point (wk 1, 2,3 , and 6). Mixed-model analysis with repeated measurements was performed using the REML procedure in GenStat 12th Edition software (2009; VSN International Ltd., Hemel Hempstead, UK). Treatment days and DIM were included as fixed effects in the model (both linear and quadratic) to estimate the slope of the curve for each treatment group. Cow, block, experimental week, and the cow by week interaction were included as random effects in the model. The model structure was (Zom et al., 2011) as follows:

$\log (Y)_{i j k}=\beta_{0}+\beta_{1} \mathrm{DIM}+\beta_{2} \mathrm{DIM}_{i}^{2}+\beta_{3} \mathrm{TD}_{j}+\beta_{4} \mathrm{TD}_{j}^{2}+\varepsilon_{i j k}$,

where $\log (Y)=$ the $\log$-transformed ratios of each of the analyzed genes versus $A C T B, \beta_{0}=$ the intercept, $\beta_{1}$ $=$ the fixed effect for $\operatorname{DIM}_{i}, \beta_{2}=$ the fixed quadratic effect of $\mathrm{DIM}_{i}^{2}, \beta_{3}=$ the effect of treatment day $\mathrm{TD}_{j}$ (control: TD $=0), \beta_{4}=$ the quadratic effect of treatment day $\mathrm{TD}_{j}^{2}$ (control: $\mathrm{TD}=0$ ), and $\varepsilon_{i j k}=$ residual variance.

Differences were declared significant at $P<0.05$. The quadratic effect of DIM and effect of TD and TD 2 were removed from the model if parameters were nonsignificant $(P>0.05)$.

\section{RESULTS AND DISCUSSION}

We have reported that the level of liver TAG was significantly reduced in the first week after calving for the CHOL compared with the CON group $(P<0.05)$, indicating that RPC supplementation during the periparturient period reduced hepatic TAG accumulation (Zom et al., 2011). Moreover, DMI and milk protein concentration for the CHOL group were significantly 
higher than for the CON group at the start of lactation $(P<0.05)$, but this effect gradually decreased as lactation progressed (Zom et al., 2011). In the present study, we aimed to develop understanding on the molecular mechanisms through which RPC affects hepatic FA metabolism by analyzing the role of 18 enzymes in liver and adipose tissue as depicted in Figures 1 and 2, respectively.

\section{Effects in Liver}

Transcription Factors. Genes belonging to the $P P A R$ family of ligand-activated nuclear transcription factors can be activated by NEFA and their derivatives, thereby controlling the expression of several genes involved in lipid metabolism. Three isoforms of PPAR are known: PPAR $\alpha, \operatorname{PPAR} \delta$, and PPAR $\gamma$ (Alaynick, 2008), of which PPAR $\gamma$ is essentially expressed in adipose tissue, where it regulates adipogenesis. Isoform PPAR $\alpha$ is mainly involved in expression of genes involved in lipid oxidation, ketogenesis, and gluconeogenesis in the liver. Peroxisome proliferator-activated receptor $\beta / \delta$ activation in rodents controls carbohydrate catabolism and FA synthesis in the liver (Takahashi et al., 2007).

As presented in Table 3 and Figure 3, the hepatic mRNA abundance of PPAR $\alpha$ increased significantly with increasing DIM, but was unaffected by RPC treatment. The expression of PPAR $\alpha$ in ruminant liver is mainly induced by plasma NEFA levels, as shown in dairy cows during the periparturient period (Loor et al., 2005) and during fasting-induced ketosis (Loor et al., 2007). van Dorland et al. (2009), however, did not observe a periparturient rise in PPAR $\alpha \mathrm{mRNA}$ and they ascribed this to the relatively low plasma NEFA concentration observed in their study (average peak concentration of approximately 0.3 to $0.5 \mathrm{mmol} / \mathrm{L}$ in wk 2 postpartum). In our experiment, NEFA levels were equal in both treatment groups, which is consis-

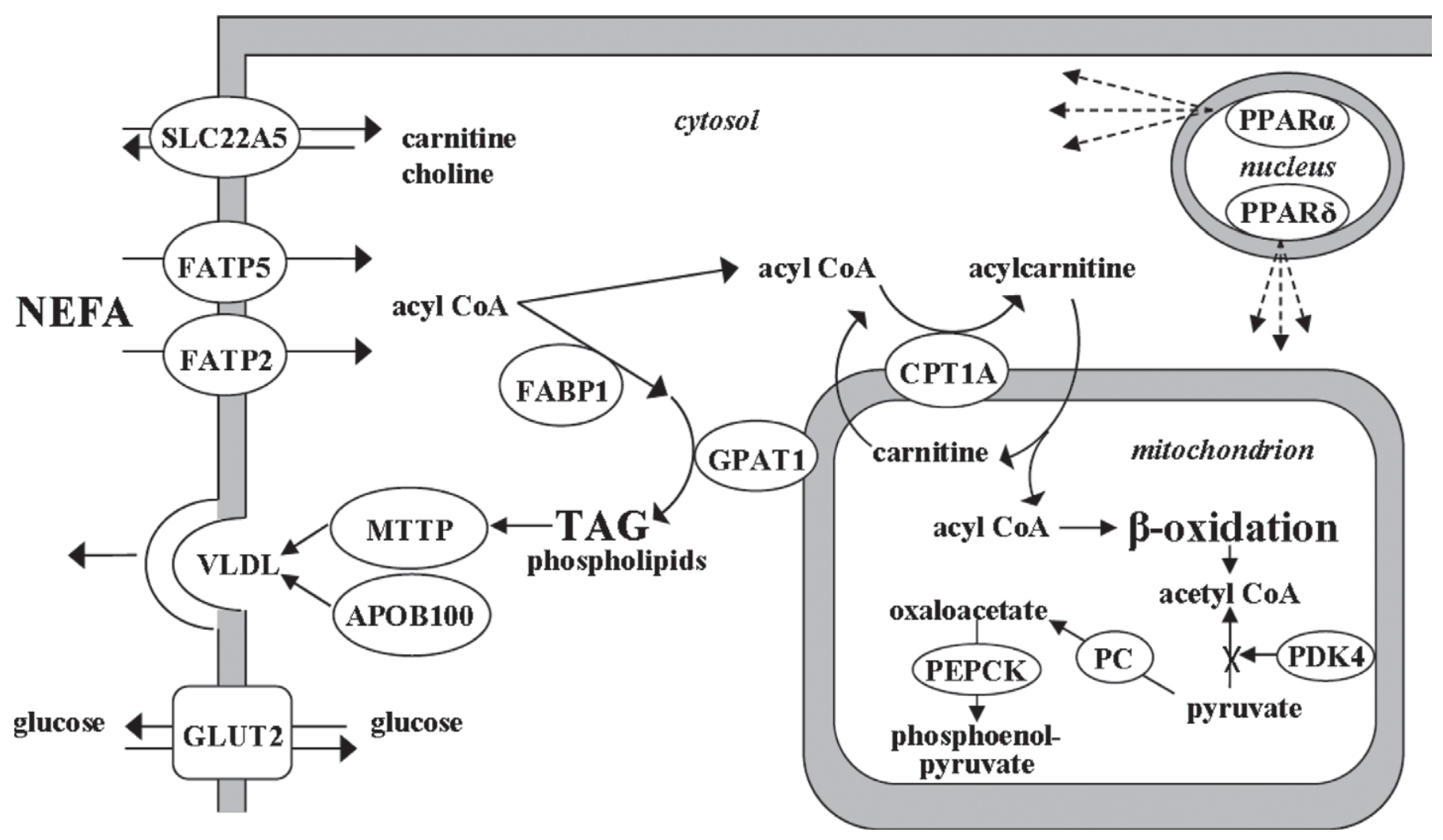

Figure 1. Model of NEFA uptake and metabolism in hepatocytes. Cellular uptake of NEFA by hepatocytes is facilitated by FA transport proteins 2 and 5 (FATP2 and FATP5), which are predominantly localized to the plasma membrane. Cytoplasmic FA are then either directed toward triacylglycerol (TAG) synthesis by the action of glycerol-3-phosphate O-acyltransferase 1 (GPAT1) and storage in lipid droplets, or toward mitochondria or peroxisomes (in the case of branched- and very-long-chain FA) for $\beta$-oxidation. Excretion of stored TAG is facilitated by microsomal triglyceride transfer protein (MTTP) in the endoplasmic reticulum, followed by very-low-density lipoproteins (VLDL) secretion. The nuclear peroxisome proliferator-activated receptors $(\mathrm{PPAR}) \alpha$ and $\delta$ modulate gene expression to regulate FA metabolism in the liver. FATP2 $=$ SLC27A2; FATP5 = SLC27A5; FABP1 = FA-binding protein 1; APOB100 = apolipoprotein B100; SLC22A5 = organic cation transporter (also known as OCTN2); CPT1A = carnitine palmitoyltransferase 1A; GLUT2 = glucose transporter 2 (or SLC2A2); PC = pyruvate carboxylase; PDK4 = pyruvate dehydrogenase kinase isotype 4; PEPCK = phosphoenolpyruvate carboxykinase. 
tent with equal PPAR $\alpha$ concentrations for both treatment groups.

For $P P A R \delta$, a significant effect of DIM as well as RPC treatment was observed, with increasing PPAR $\delta$ mRNA abundance for cows in the CHOL group and decreasing mRNA levels in the CON group (Table 3 and Figure 3$)$. In a study with dairy cows, $P P A R \delta$ mRNA expression was increased in severely feed-restricted ketotic cows compared with healthy cows; the ketotic cows showed increased liver TAG, plasma NEFA, and BHBA concentrations (Loor et al., 2007). Peroxisome proliferator-activated receptor $\delta$ expression showed to be increased by FA; activation of $P P A R \delta$ is involved in regulatory loops for lipid oxidation and lipid transport (Loor et al., 2007). Recent in vitro studies confirmed that specific MUFA, including oleic acid, activate PPAR expression (Brown et al., 2011). In rodents, PPAR $\delta$ activation improves glucose utilization and lipoprotein metabolism, and exerts an antiinflammatory effect in the liver (Sanderson et al., 2010). Although differences in PPAR $\delta$-dependent pathways may exist for each different species, taken together with the results of Loor et al. (2007) in dairy cattle, these results confirm that $P P A R \delta$ activation is needed for optimal FA processing at increased FA influxes in the liver around parturition.

FA Transport. The integral membrane proteins FATP2 and FATP5 function as hepatic transporters for long-chain FA, activating them to acyl-CoA (Kazantzis and Stahl, 2012). Although FATP2 is predominantly a plasma membrane transporter transporting $\mathrm{FA}$ into the cytosol (Figure 1), a minor fraction is localized in liver peroxisomes, allowing peroxisomal oxidation of branched and very-long-chain FA (Falcon et al., 2010). We did not observe a significant effect of DIM for FATP2 mRNA level, nor did RPC treatment change the levels of expression (Table 3 and Figure 3 ).

For FATP5, a significant effect of treatment on mRNA transcript was observed (Table 3 ). The mRNA abundance of this transporter increased in CHOL cows postpartum (Figure 3), suggesting that RPC facilitates the import of FA into the liver after calving. Because the stimulatory effect on FATP5 expression was paralleled by an increased PPAR $\delta$ expression (Figure 3), it would be interesting to investigate in further studies

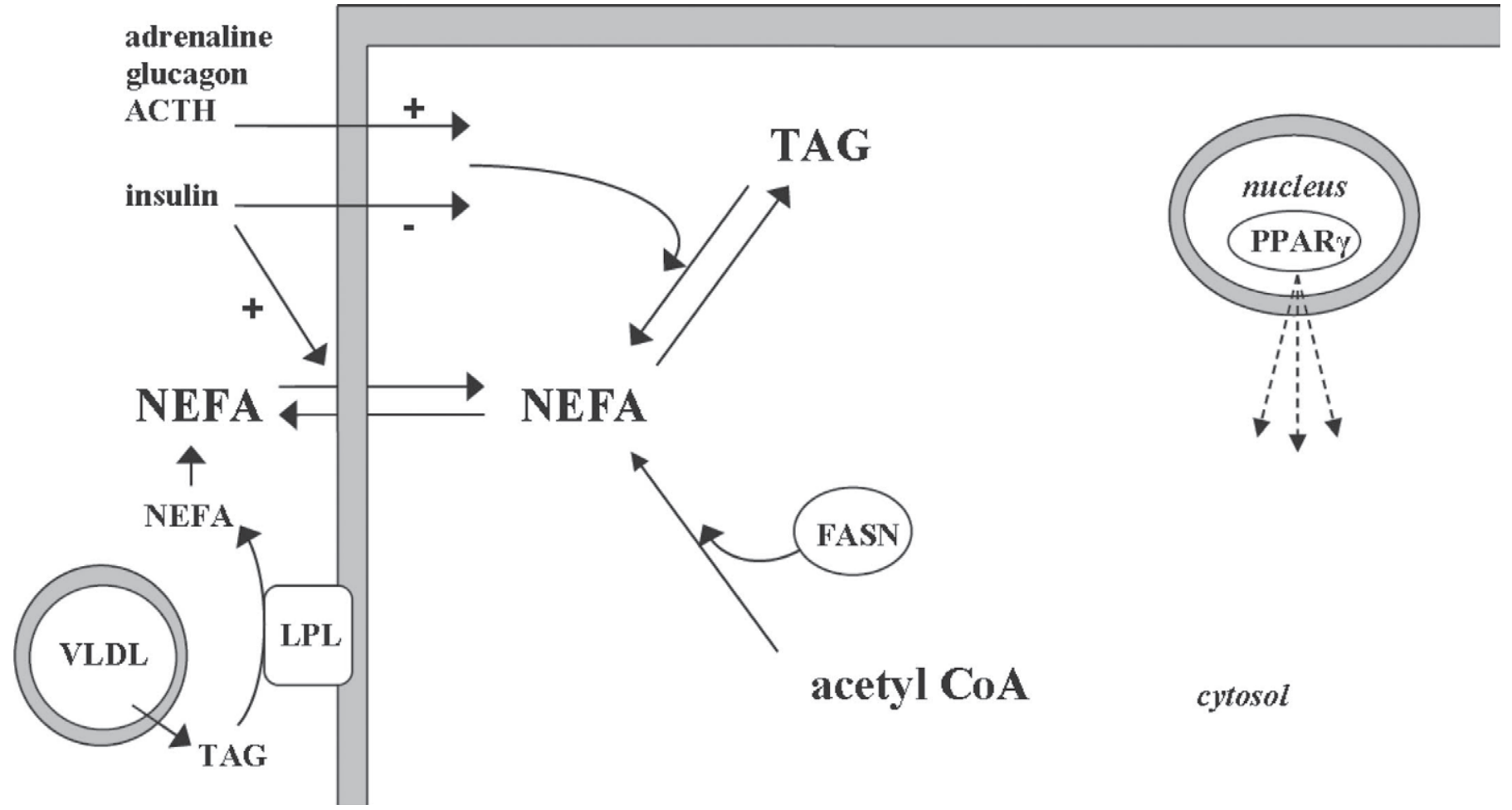

Figure 2. Model of NEFA metabolism in adipocytes. The balance between lipogenesis and lipolysis in adipocytes is determined by the nutritional state and is regulated by endocrine factors including ACTH, glucagon, adrenalin, and insulin. Under conditions of a positive energy balance, NEFA released from lipoproteins [e.g., very-low-density lipoproteins (VLDL) and chylomicrons by the catalytic activity of lipoprotein lipase (LPL)] enter the adipocytes through both passive diffusion and active transport. Intracellular FA are first converted to acyl-CoA and then reassembled into triacylglycerol (TAG), which can be stored in lipid droplets. Alternatively, NEFA can be synthesized de novo by FA synthase (FASN), using acetyl-CoA as a substrate. During a state of negative energy balance, the hydrolysis of TAG to NEFA in adipocytes prevails. Subsequently, NEFA are released into the circulation to supply energy to other organs. The nuclear receptor peroxisome proliferator-activated receptor $\gamma(\operatorname{PPAR} \gamma)$ is known to target genes involved in FA metabolism and adipocyte differentiation. 
Table 3. The effect of choline supplementation on gene expression in liver and adipose tissue expressed as the relative ratio with housekeeping gene $\beta$-actin $(A C T B)$ mRNA concentration ${ }^{1}$

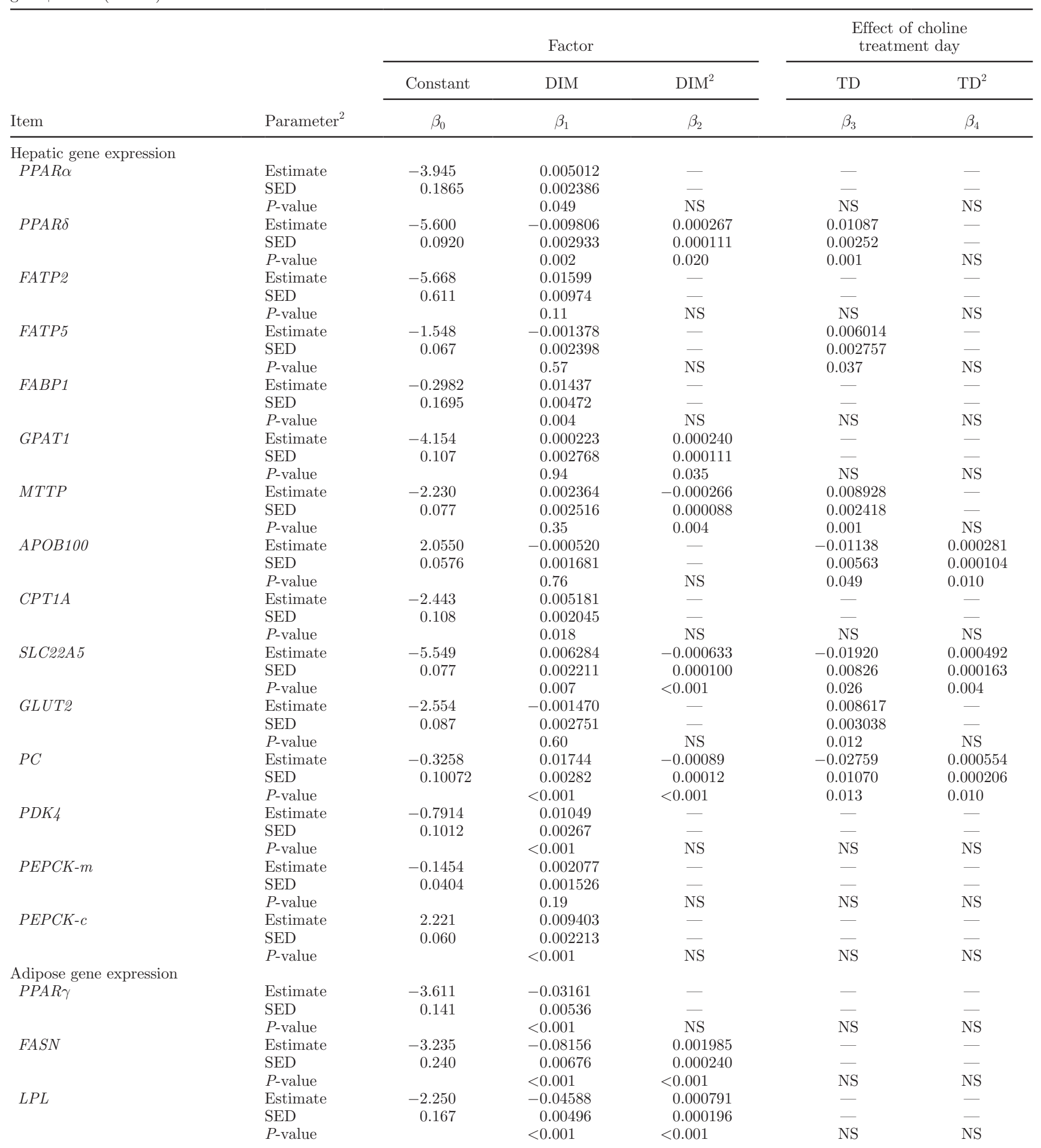

${ }^{1}$ Analyzed using the statistical model $\log (Y)_{i j k}=\beta_{0}+\beta_{1} \mathrm{DIM}+\beta_{2} \mathrm{DIM}_{i}^{2}+\beta_{3} \mathrm{TD}_{j}+\beta_{4} \mathrm{TD}_{j}^{2}+\varepsilon_{i j k}$, where log $(Y)=$ the log-transformed gene expression ratios, $\beta_{0}=$ the intercept, $\beta_{1}=$ the fixed effect for $\mathrm{DIM}_{i}, \beta_{2}=$ the fixed quadratic effect of $\mathrm{DIM}_{i}^{2}, \beta_{3}=$ the effect of treatment day TD (control: $\mathrm{TD}=0), \beta_{4}=$ the quadratic effect of treatment day $\mathrm{TD}_{j}^{2}($ control: $\mathrm{TD}=0)$, and $\varepsilon_{i j k}=$ the residual variance. Parameters were declared significant at $P<0.05$; NS parameters for $\mathrm{DIM}^{2}$, TD, and $\mathrm{TD}^{2}$ were released from the model.

${ }^{2} \mathrm{SED}=$ standard error of difference. 
whether this stimulatory effect could be attributed to the mediatory action of PPAR $\delta$.

Similarly to PPAR $\alpha$ expression, the mRNA abundance of FABP1 increased significantly with DIM but was unaffected by RPC treatment (Figure 3). Fatty acid-binding protein 1, also known as liver-type FAbinding protein, is a cytosolic protein that binds and transports NEFA between membranes. In addition, FABP1 can physically interact with PPAR $\alpha$, explaining its partially nuclear localization (Wolfrum et al., 2001; Schroeder et al., 2008) and activation of transcription by PPARo (Rakhshandehroo et al., 2010). This lack of a treatment effect on FABP1 expression thus confirms that the effect of choline supplementation on liver metabolism is not implemented through PPAR $\alpha$ activation.

Esterification and TAG Transport. Once taken up by the hepatocyte, NEFA can be esterified into TAG either for delivery into blood as VLDL or storage as cytosolic lipid droplets (Figure 1). The first, rate-limiting step in TAG synthesis is the attachment of activated NEFA (i.e., acyl-CoA) at the sn-1 position of glycerol3 -phosphate, a process catalyzed by GPAT1 (Takeuchi and Reue, 2009).

We found a significant effect of DIM on GPAT1 mRNA expression, with increasing expression postpartum (Table 3 and Figure 3). Loor et al. (2005, 2006) described a comparable expression pattern of GPAT1 around parturition, with lowest levels at calving. In our study, the lowest levels of GPAT1 mRNA in wk 1 (Figure 3) coincided with peak hepatic TAG concentration in wk 1 (Zom et al., 2011) and increased levels of GPAT1 mRNA were found when the TAG concentration returned to normal levels in wk 6. Loor et al. (2006) suggested that GPAT1 expression may not be limiting for periparturient TAG accumulation. Also in our trial, the reduction of TAG accumulation by RPC supplementation was not effectuated through changes in GPAT1 expression.

Expression of MTTP was significantly affected by DIM and treatment (Figure 3). In CON cows, the MTTP mRNA level was increased significantly at wk 1 and decreased gradually below antepartum level in wk 6. Our results are consistent with earlier work demonstrating that MTTP mRNA levels in the bovine liver are highest around parturition (Bernabucci et al., 2004). In response to RPC supplementation, however, this increase at parturition was sustained during the first 6 wk (Figure 3). As MTTP promotes VLDL assembly in the endoplasmic reticulum (Wetterau et al., 1997), this result suggests that RPC increases VLDL assembly and, thus, TAG export from the liver, allowing hepatocytes to cope with the elevated NEFA influx during early lactation.
For APOB100, mRNA levels were also significantly affected by treatment (Figure 3). Cows in group CON did not show a change in APOB100 mRNA, whereas CHOL cows had increased levels of $A P O B 100$ in wk 6 postpartum. We did not find a pronounced decrease in $A P O B 100$ immediately postpartum as described by Bernabucci et al. (2004), but the increased mRNA levels of APOB100 and MTTP with RPC treatment suggest that improved VLDL synthesis is a main route of reduced TAG concentration in early lactation with RPC supplementation.

FA Buffering and Mitochondrial Transport. We observed a significant effect of DIM on the CPT1A mRNA level (Figure 3). It has been well established that CPT1A is responsible for the regulation of mitochondrial $\beta$-oxidation in liver. In previous studies, $C P$ $T 1 A$ expression levels in dairy cattle in early lactation were variable (Loor et al., 2005, 2006; Selberg et al., 2005; van Dorland et al., 2009). The hepatic CPT1A gene is a known target of PPAR $\alpha$ in mouse and human (Rakhshandehroo et al., 2010) as well as in dairy cattle (Loor et al., 2005; van Dorland et al., 2009) and this relationship between the expression levels of PPAR $\alpha$ and CPT1A is also found in our study with increasing DIM. Treatment had no effect on PPAR $\alpha$ expression (as mentioned above), nor on CPT1A mRNA abundance. This suggests that RPC supplementation did not affect $\mathrm{FA}$ transport into mitochondria.

We found that SLC22A5 mRNA abundance was significantly affected by DIM and treatment, with increased expression around parturition (Figure 3). This is the first study in which hepatic SLC22A5 expression is explicitly analyzed in periparturient dairy cattle. As a plasma membrane transporter, SLC22A5 facilitates the import of carnitine and other organic cations into the hepatocyte (Koepsell et al., 2007; Figure 1). Carnitine is an obligatory cofactor for $\beta$-oxidation of FA, enabling the transport of long-chain FA across the inner mitochondrial membrane as acylcarnitine esters (Ramsay and Arduini, 1993). The increased expression of SLC22A5 around parturition, therefore, suggests a need for organic cation transport into hepatocytes postpartum. In rats and pigs, increased lipolysis due to fasting led to an increased hepatic transcription of SLC22A5, facilitating carnitine transport into liver cells, buffering cytosolic FA and supporting oxidation of the increased flux of FA (Ringseis et al., 2009). The results of Grum et al. (1996) confirm that the same pathway is also active in dairy cattle, showing increased carnitine concentration in liver around calving when DMI was low. Choline has been shown to have a dual effect on carnitine availability: it can support carnitine synthesis in the liver by functioning as a methyl donor in a methylation step (Bremer, 1983) and it can also 

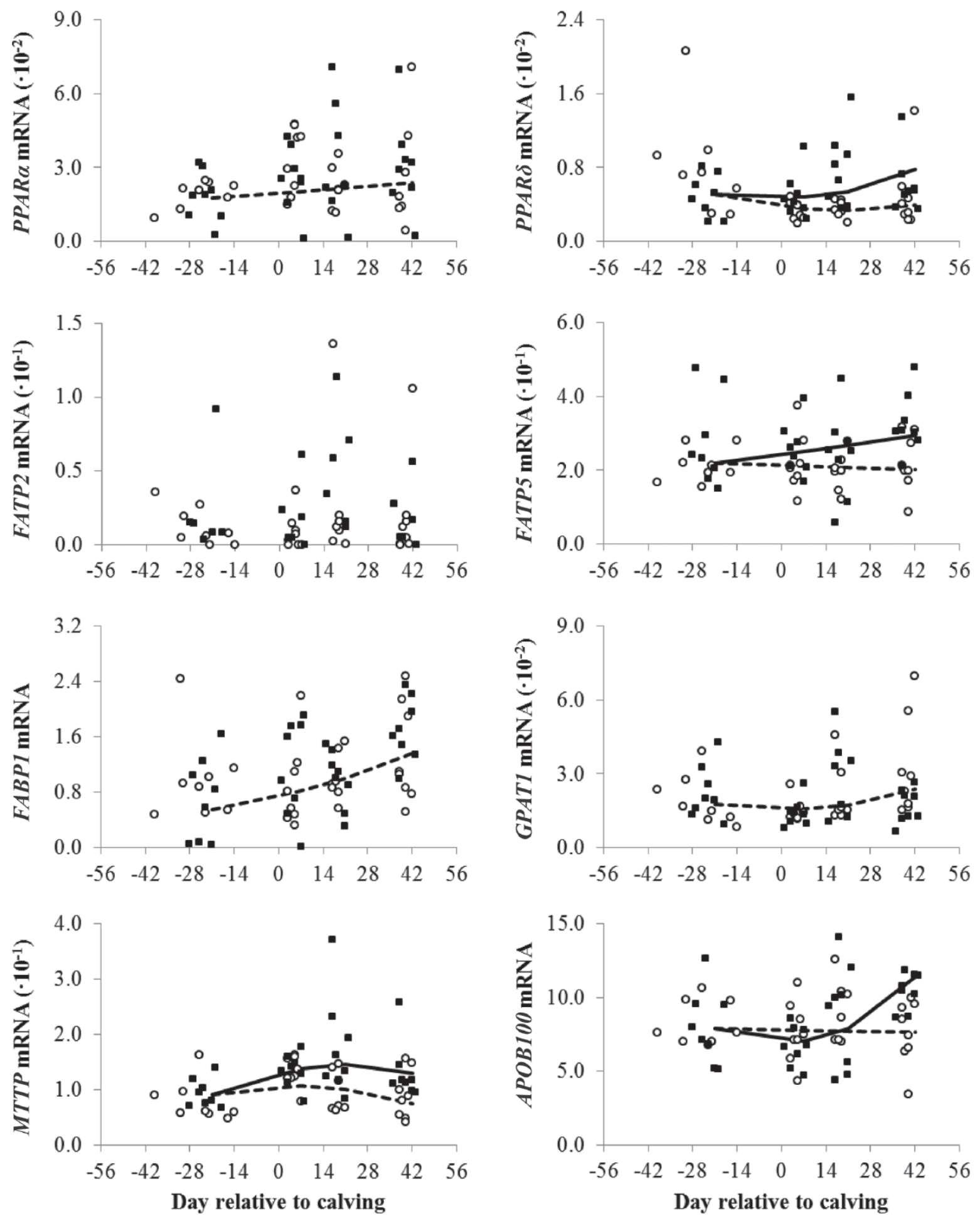

Figure 3. Effect of choline supplementation on the expression of 15 energy metabolism-related genes in hepatic tissue of periparturient dairy cows. Indicated mRNA levels are expressed as a ratio to housekeeping gene $\beta$-actin $(A C T B)$. Open symbols = cows in the control group $(\mathrm{CON})$; closed symbols = cows in the choline-supplemented group (CHOL); solid line = slope of the treatment group; broken line (when solid line is present $)=$ slope of the control group; broken line (when solid line is not present) $=$ average slope of all cows. PPAR $\alpha=$ peroxisome proliferatoractivated receptor $\alpha ; P P A R \delta=$ peroxisome proliferator-activated receptor $\delta ; F A T P 2=$ FA transport protein 2 (or SLC27A2); FATP5 $=$ FA transport protein 5 (or SLC27A5); FABP1 = FA-binding protein 1; GPAT1 = glycerol-3-phosphate acyltransferase 1 (or GPAM); MTTP = microsomal triglyceride transfer protein; APOB100 = apolipoprotein B100; SLC22A5 = organic cation transporter (also known as OCTN2); $C P T 1 A=$ carnitine palmitoyltransferase $1 \mathrm{~A} ; G L U T 2=$ glucose transporter $2($ or SLC2A2); $P C=$ pyruvate carboxylase; $P D K 4=$ pyruvate dehydrogenase kinase isotype $4 ; P E P C K=$ phosphoenolpyruvate carboxykinase. 

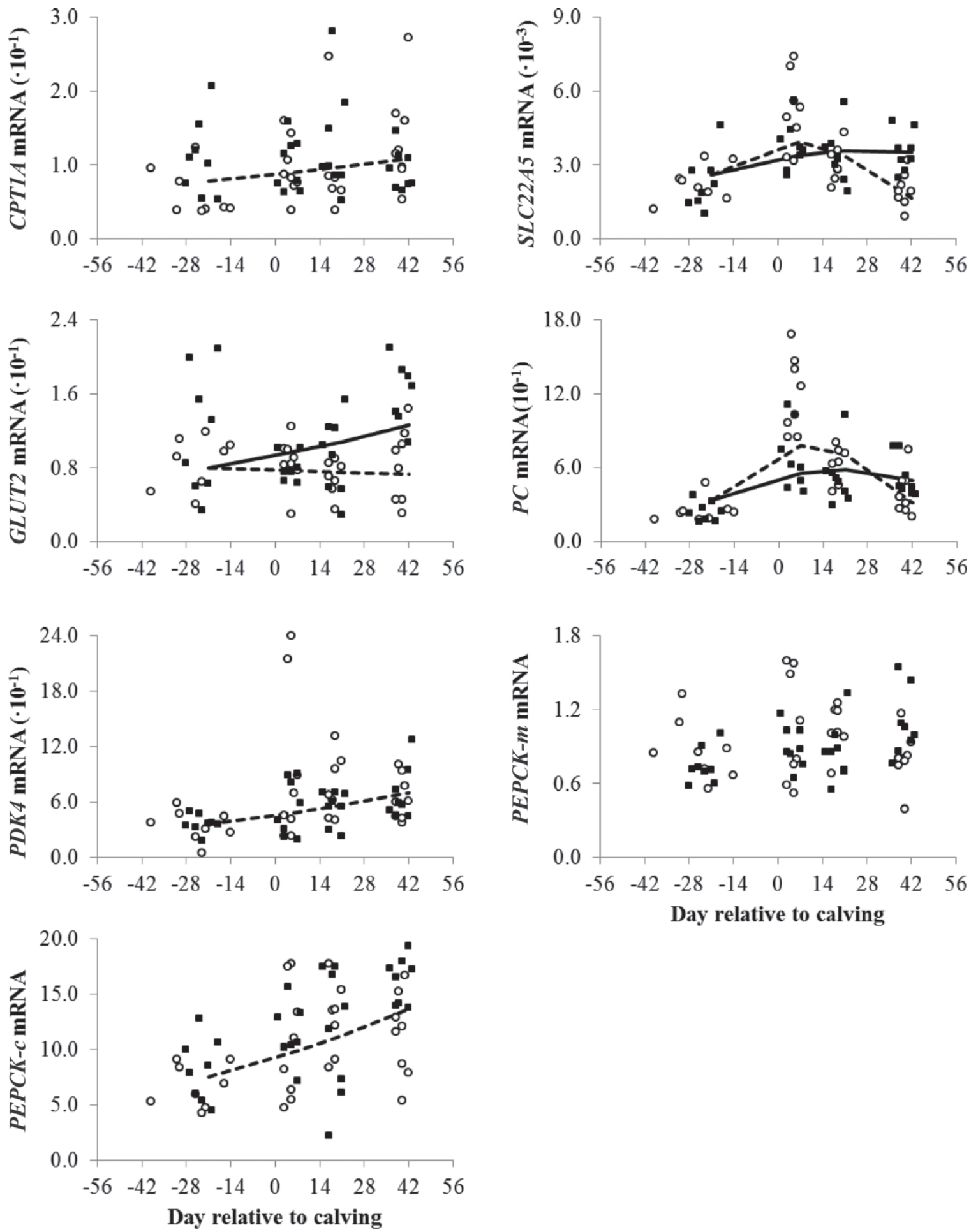

Figure 3 (Continued). Effect of choline supplementation on the expression of 15 energy metabolism-related genes in hepatic tissue of periparturient dairy cows. Indicated mRNA levels are expressed as a ratio to housekeeping gene $\beta$-actin $(A C T B)$. Open symbols $=$ cows in the control group $(\mathrm{CON})$; closed symbols = cows in the choline-supplemented group (CHOL); solid line = slope of the treatment group; broken line (when solid line is present) $=$ slope of the control group; broken line (when solid line is not present) $=$ average slope of all cows. PPAR $\alpha$ $=$ peroxisome proliferator-activated receptor $\alpha ; P P A R \delta=$ peroxisome proliferator-activated receptor $\delta$; FATP $2=\mathrm{FA}$ transport protein 2 (or SLC27A2); FATP5 = FA transport protein 5 (or SLC27A5); FABP1 = FA-binding protein 1: GPAT1 = glycerol-3-phosphate acyltransferase 1 (or GPAM); $M T T P=$ microsomal triglyceride transfer protein; APOB100 = apolipoprotein B100; SLC22A5 = organic cation transporter (also known as OCTN2); CPT1A = carnitine palmitoyltransferase 1A; GLUT2 = glucose transporter 2 (or SLC2A2); PC = pyruvate carboxylase; $P D K 4=$ pyruvate dehydrogenase kinase isotype $4 ; P E P C K=$ phosphoenolpyruvate carboxykinase. 
directly stimulate the transport of dietary carnitine into liver cells as found in rats (Carter and Frenkel, 1978). Choline-induced SLC22A5 expression may have resulted in an increased intracellular carnitine concentration in RPC-supplemented cows. Increased carnitine availability has been found to reduce liver TAG accumulation in dairy cattle through a stimulation of FA oxidation, as well as an improved gluconeogenesis (Carlson et al., 2007). Serum BHBA concentrations were found to be higher with carnitine supplementation, as a result of increased NEFA oxidation (Carlson et al., 2007). In our study, plasma BHBA concentrations were not significantly different between treatment groups (Zom et al., 2011), suggesting that a potential increase in FA oxidation by RPC supplementation was not substantial.

Pyruvate Metabolism and Glucose Transport. We analyzed mRNA expression of GLUT2, the bidirectional glucose transporter in the plasma membrane (Zhao et al., 1993), to evaluate the glucogenic status of the liver. As shown in Figure 3 and Table 3 no significant effect of DIM existed on GLUT2 mRNA abundance, as was also found by Hammon et al. (2009), but RPC increased GLUT2 expression postpartum. Because GLUT2 is a glucose-sensitive gene in the liver (Leturque et al., 2005), increased GLUT2 expression in the CHOL group could be a result of higher glucose production in the liver, indicating improved carbohydrate metabolism. The increase in glucose output will support the energy demand of other organs, such as the mammary gland. However, RPC had no significant influence on milk yield or lactose yield (Zom et al., 2011).

Additionally, mRNA expression of 4 genes involved in gluconeogenesis was analyzed. Pyruvate carboxykinase was significantly increased in wk 1 postpartum, and decreased again in the first 6 wk of lactation. In cows supplemented with RPC, this periparturient increase was significantly lower. Pyruvate carboxykinase is important in gluconeogenesis and formation of oxaloacetate, and expression is upregulated around parturition in cows with lower energy status or high liver fat content (Loor et al., 2007; Hammon et al., 2009; Castro et al., 2012). The reduced expression in CHOL cows relative to CON cows suggests that RPC supplementation improved energy status and reduced the need for PC.

No effect of treatment was observed on $P E P C K-m$ or $P E P C K-c$, but $P E P C K-c$ mRNA increased significantly with DIM as also found by Hammon et al. (2009) when looking at cows with relatively high compared with low liver fat concentration. The same effect of an increase in $P C$ but not in PEPCK- $m$ or PEPCK-c expression was found after sever feed restriction in mid-lactation dairy cattle (Velez and Donkin, 2005).
Pyruvate dehydrogenase kinase isotype 4 is involved in the inactivation of pyruvate dehydrogenase and forms a regulating link between fat and carbohydrate metabolism in mammals: expression of PDK4 is increased in starvation and with increased intracellular lipid concentration, thereby favoring the oxidation of long-chain FA over pyruvate as an energy substrate (Holness and Sugden, 2003; Connaughton et al., 2010). Pyruvate dehydrogenase kinase isotype 4 mRNA expression is induced by glucocorticoids and reduced by insulin (Connaughton et al., 2010). In dairy cows, PDK4 expression was increased in endometrial tissue of animals in severe negative energy balance (Wathes et al., 2011). To our knowledge, expression has not been analyzed in dairy cow hepatic tissue before. In our study, an increase in $P D K_{4}$ expression occurred with DIM, suggesting increasing utilization of FA over carbohydrate energy sources, but we did not find a significant effect of treatment.

\section{Effects in Adipose Tissue}

During the dry period, adipose tissue metabolism is in an anabolic state, with high $P P A R \gamma$ expression, altering gene expression to direct adipose cells toward lipogenesis and enhanced glucose uptake (Walczak and Tontonoz, 2002). Around parturition, lipolysis in adipose tissue is favored over lipogenesis to mobilize FA for lactogenesis in the mammary gland. To evaluate whether RPC supplementation had an effect on lipogenesis, we analyzed the transcript levels of the following 3 genes in adipose tissue: PPAR $\gamma, F A S N$, and $L P L$. Peroxisome proliferator-activated receptor $\gamma$ is the transcription factor for lipogenesis in adipocytes, known to target the FASN and $L P L$ genes (Thering et al., 2009). Fatty acid synthase catalyzes FA synthesis, whereas LPL promotes the cellular uptake of FA from VLDL in the bloodstream. For each of these genes expressed during our trial, a significant effect of DIM was observed, with the highest gene expression level before calving, followed by a sharp decrease postpartum (Table 3 and Figure 4) as expected. After calving, catabolic processes result in lipolysis, sharply decreasing the expression of these genes. Above this, no significant effect of treatment was observed (Table 3 and Figure 4), indicating that RPC supplementation had no effect on FA metabolism in adipose tissue when considering the 3 genes evaluated.

\section{Milk Fat}

The effect of RPC on the amount of FA mobilization from adipose tissue can be evaluated indirectly by considering the FA composition of milk. Short- and 

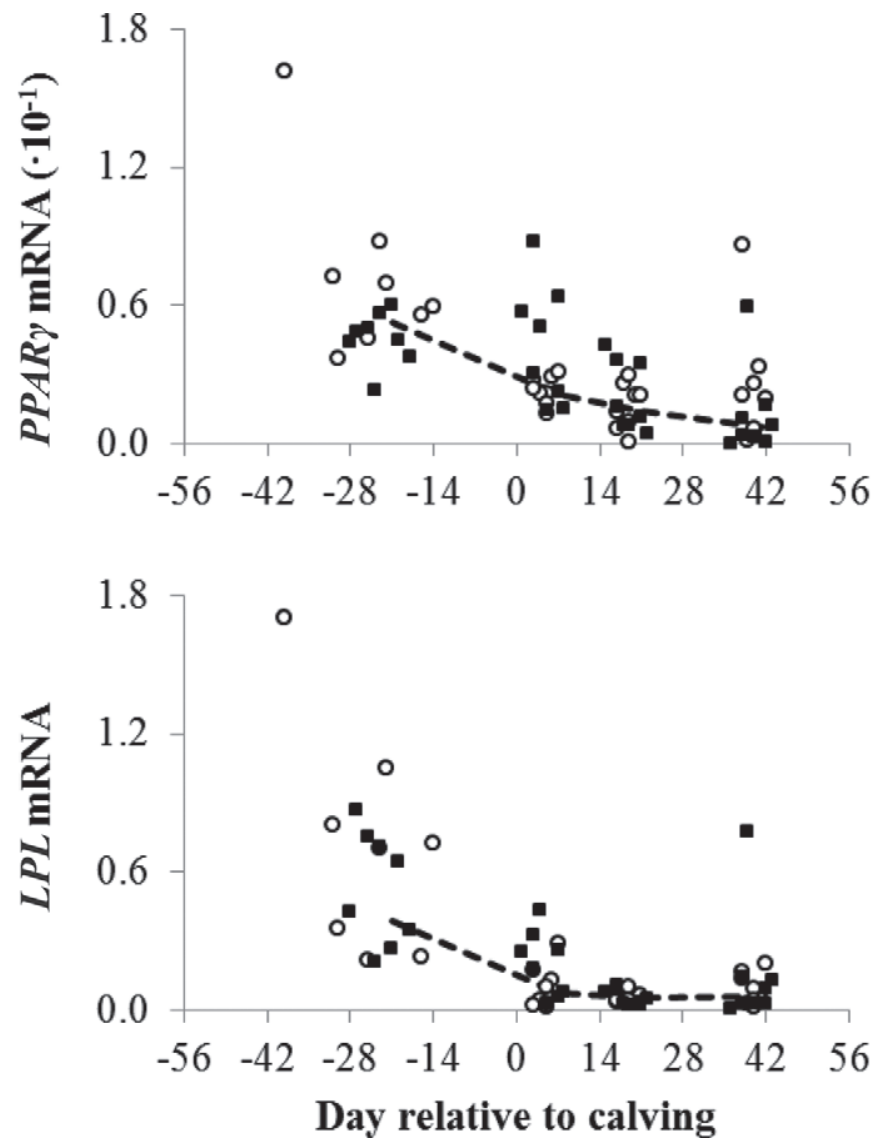

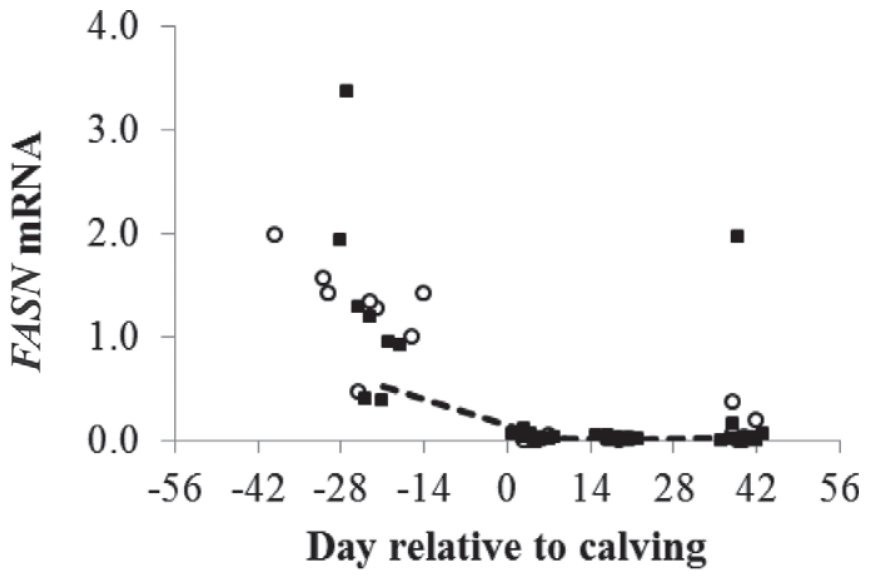

Figure 4. Quantitative PCR analysis of the expression of 3 fat metabolism-related genes in adipose tissue of periparturient dairy cows. Indicated mRNA levels are expressed as a ratio to housekeeping gene $\beta$-actin $(A C T B)$. Open symbols $=$ cows in the control group $(\mathrm{CON})$; closed symbols $=$ cows in the choline-supplemented group $(\mathrm{CHOL})$; broken line $=$ effect of DIM (Table $3 ; P<0.05) . P P A R \gamma=$ peroxisome proliferatoractivated receptor $\gamma ; L P L=$ lipoprotein lipase; $F A S N=$ FA synthase.

medium-chain FA $(<\mathrm{C} 16: 0)$ as well as part of C16:0 FA in milk fat originate from de novo synthesis in the mammary gland, whereas longer-chain FA originate from dietary fat or mobilization from adipose tissue (Mansbridge and Blake, 1997). Reduced mobilization from adipose tissue will decrease the relative proportion of long-chain FA compared with short- and medium-chain FA in milk. Results for FA composition are presented in Table 4.

As expected, the milk FA composition was significantly affected by DIM. The proportion of short- and medium-chain FA originating from de novo synthesis in the mammary gland increased, whereas long-chain FA originating from adipose tissue (C18:0 and C18:1 in milk) decreased $(P<0.001)$ with time postpartum.

No significant effect of treatment was observed on milk FA originating from de novo synthesis, implying that choline supplementation did not affect the balance between de novo synthesis of FA and the mobilization of FA from adipose tissue. This corresponds with the lack of treatment effect for BCS and plasma NEFA con- centration as published previously (Zom et al., 2011). No indication exists, therefore, that RPC affected the amount of lipolysis in adipose tissue, in agreement with the absence of an effect of RPC on the tested lipogenic genes in adipose tissue (Table 3 and Figure 4). Two specific FA with a relatively small contribution to the total amount of milk FA [cis-9,trans-11 C18:2 (rumenic acid) and trans-9 C18:1] were significantly affected by treatment days. Both FA specifically originate from incomplete biohydrogenation of dietary PUFA in the rumen. Their contribution to milk FA was increased for the CHOL group. On both treatments, cows received equal amounts of concentrate during the trial (Table 1), but voluntary DMI of the roughage feed mixture was increased during the first weeks of lactation for the CHOL group (Zom et al., 2011). This feed mixture consisted mainly of $52 \%$ wilted grass silage and $35 \%$ corn silage (Table 1). The increased intake of the forage mixture increased the amount of dietary PUFA ingested and may also have caused changes in factors affecting rumen biohydrogenation of PUFA (e.g., rumen $\mathrm{pH}$ and 
Table 4. The effect of choline supplementation on the proportion of FA (g/100 g of FA) in the a.m. milk during the first 6 wk of lactation ${ }^{1}$

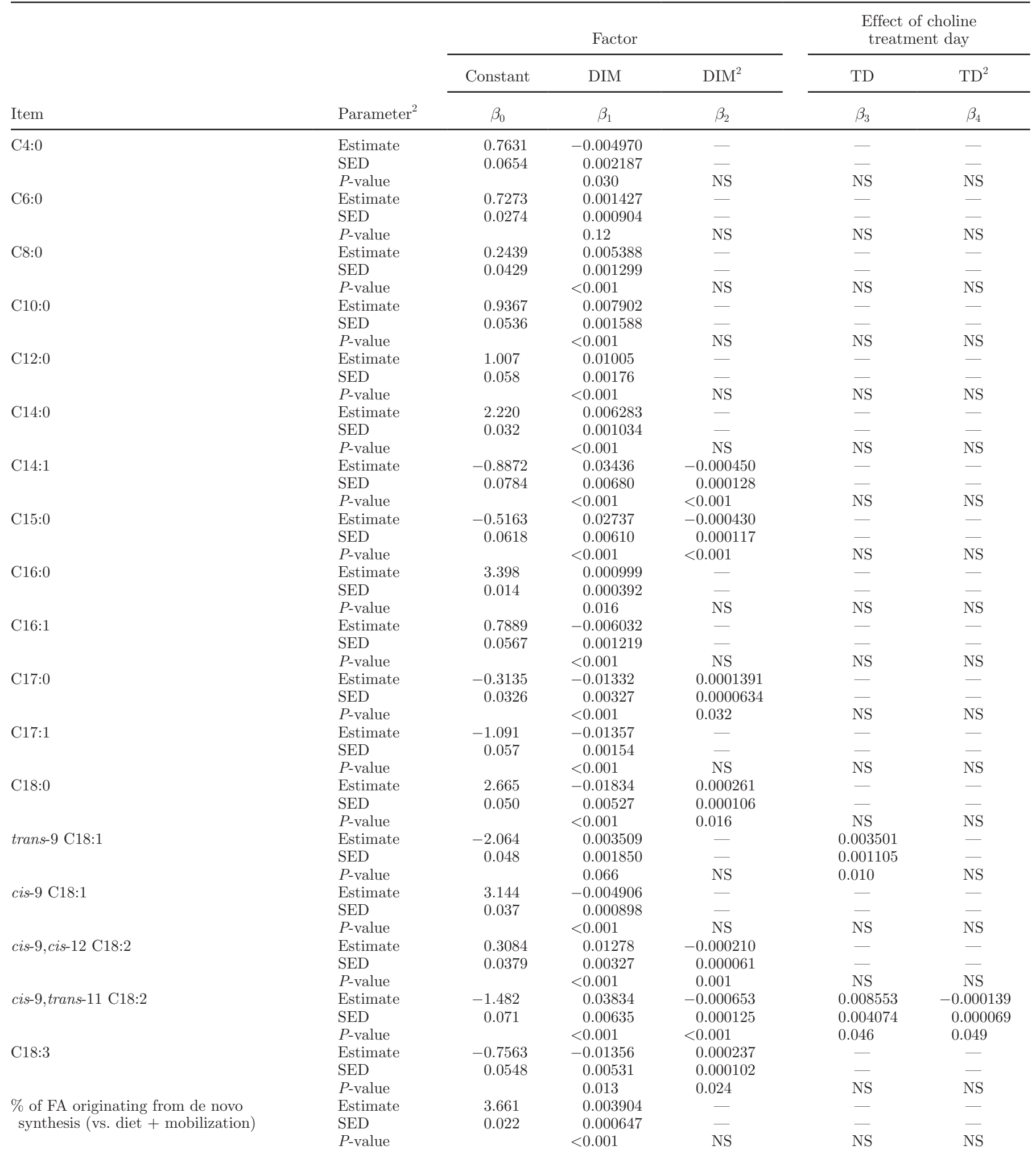

${ }^{1}$ Analyzed using the statistical model $\log (Y)_{i j k}=\beta_{0}+\beta_{1} \mathrm{DIM}+\beta_{2} \mathrm{DIM}_{i}^{2}+\beta_{3} \mathrm{TD}_{j}+\beta_{4} \mathrm{TD}_{j}^{2}+\varepsilon_{i j k}$, where $\log (Y)=$ the log-transformed $\mathrm{FA}($ in $\mathrm{g} / 100 \mathrm{~g}$ total FA), $\beta_{0}=$ the intercept, $\beta_{1}=$ the fixed effect for $\mathrm{DIM}_{i}, \beta_{2}=$ the fixed quadratic effect of $\mathrm{DIM}_{i}^{2}, \beta_{3}=$ the effect of treatment day $\mathrm{TD}_{j}$ (control: $\left.\mathrm{TD}=0\right), \beta_{4}=$ the quadratic effect of treatment day $\mathrm{TD}_{j}^{2}\left(\right.$ control: $\mathrm{TD}=0$ ), and $\varepsilon_{i j k}=$ the residual variance. Parameters were declared significant at $P<0.05$; NS parameters for $\mathrm{DIM}^{2}$, TD, and $\mathrm{TD}^{2}$ were released from the model.

${ }^{2} \mathrm{SED}=$ standard error of difference.

Journal of Dairy Science Vol. 96 No. 2, 2013 
rumen transit time), resulting in increased proportions of rumenic acid in milk fat (Griinari et al., 1998).

\section{CONCLUSIONS}

The beneficial effect of RPC on hepatic lipidosis during the first weeks postpartum, as observed by Zom et al. (2011), could not be attributed to a difference in the amount of adipose tissue lipolysis, as no treatment effect was observed on (1) gene expression in adipose tissue, (2) NEFA concentration in blood (Zom et al., 2011), or (3) milk FA composition. Our results indicate that the RPC-reduced hepatic TAG concentration is most likely attributed to a combination of (1) improved buffering and transport of intracellular NEFA by increased carnitine concentration, as evidenced by the increase in PPARS, FATP5, and SLC22A5 expression; (2) improved excretion by VLDL transport, shown by increased MTTP and APOB100 mRNA expression; and (3) improved carbohydrate metabolism, shown by increased GLUT2 expression postpartum and reduced $P C$ peak expression levels immediately after calving. Overall, RPC supplementation improved hepatic energy metabolism. Choline may have been the rate-limiting nutrient in VLDL assembly, resulting in TAG accumulation in unsupplemented cows during the first weeks postpartum. Finally, we hypothesize that the beneficial effects of RPC on liver function are extended beyond the period of hepatic lipidosis, because mRNA abundance of genes highly relevant in energy metabolism (SLC22A5, MTTP, APOB100, and GLUT2) were still affected in wk 6, when DMI between groups was equal and hepatic TAG concentration had already returned to normal levels.

\section{ACKNOWLEDGMENTS}

The authors acknowledge Johan van Riel (Wageningen UR Livestock Research, Lelystad, the Netherlands) for statistical support, the staff of experimental farm De Waiboerhoeve (Lelystad, the Netherlands) for their contribution to this experiment, and the staff of Veterinary Practice Flevoland (Zeewolde, the Netherlands) for collecting biopsies. This experiment was funded by the Dutch Ministry of Economic Affairs, Agriculture and Innovation (The Hague, the Netherlands), by Speerstra Feed Ingredients (Lemmer, the Netherlands), and by Balchem Corporation (New Hampton, NY). We thank Ric Grummer and Barbara Barton (Balchem Corp.) for critical reading and comments on earlier versions of this manuscript.

\section{REFERENCES}

Alaynick, W. A. 2008. Nuclear receptors, mitochondria and lipid metabolism. Mitochondrion 8:329-337.
Bernabucci, U., B. Ronchi, L. Basiricò, D. Pirazzi, F. Rueca, N. Lacetera, and A. Nardone. 2004. Abundance of mRNA of apolipoprotein $\mathrm{B}_{100}$, apolipoprotein $\mathrm{E}$, and microsomal triglyceride transfer protein in liver from periparturient dairy cows. J. Dairy Sci. $87: 2881-2888$

Bremer, J. 1983. Carnitine-Metabolism and functions. Physiol. Rev. 63:1420-1480.

Brown, J. D., E. Oligino, D. J. Rader, A. Saghatelian, and J. Plutzky. 2011. VLDL hydrolysis by hepatic lipase regulates PPAR $\delta$ transcriptional responses. PLoS ONE 6:e21209.

Carlson, D. B., J. W. McFadden, A. D'Angelo, J. C. Woodworth, and J. K. Drackley. 2007. Dietary L-carnitine affects periparturient nutrient metabolism and lactation in multiparous cows. J. Dairy Sci. 90:3422-3441.

Carter, A. L., and R. Frenkel. 1978. The relationship of choline and carnitine in the choline deficient rat. J. Nutr. 108:1748-1754.

Castro, N., C. Kawashima, H. A. van Dorland, I. Morel, A. Miyamoto, and R. M. Bruckmaier. 2012. Metabolic and energy status during the dry period is crucial for the resumption of ovarian activity postpartum in dairy cows. J. Dairy Sci. 95:5804-5812.

Connaughton, S., F. Chowdhury, R. R. Attia, S. Song, Y. Zhang, M. B. Elam, G. A. Cook, and E. A. Park. 2010. Regulation of pyruvate dehydrogenase kinase isoform 4 (PDK4) gene expression by glucocorticoids and insulin. Mol. Cell. Endocrinol. 315:159-167.

Cooke, R. F., N. S. del Rio, D. Z. Caraviello, S. J. Bertics, M. H. Ramos, and R. R. Grummer. 2007. Supplemental choline for prevention and alleviation of fatty liver in dairy cattle. J. Dairy Sci. 90:2413-2418.

Drackley, J. K., S. S. Donkin, and C. K. Reynolds. 2006. Major advances in fundamental dairy cattle nutrition. J. Dairy Sci. 89:1324-1336.

Elek, P., J. R. Newbold, T. Gaal, L. Wagner, and F. Husveth. 2008. Effects of rumen-protected choline supplementation on milk production and choline supply of periparturient dairy cows. Animal 2:1595-1601.

Falcon, A., H. Doege, A. Fluitt, B. Tsang, N. Watson, M. A. Kay, and A. Stahl. 2010. FATP2 is a hepatic fatty acid transporter and peroxisomal very long-chain acyl-CoA synthetase. Am. J. Phys. Endocrinol. Metab. 299:E384-E393.

Friggens, N. C., J. B. Andersen, T. Larsen, O. Aaes, and R. J. Dewhurst. 2004. Priming the dairy cow for lactation: A review of dry cow feeding strategies. Anim. Res. 53:453-473.

Griinari, J. M., D. A. Dwyer, M. A. McGuire, D. E. Bauman, D. L. Palmquist, and K. V. V. Nurmela. 1998. Trans-octadecenoic acids and milk fat depression in lactating dairy cows. J. Dairy Sci. 81:1251-1261.

Grum, D. E., J. K. Drackley, R. S. Younker, D. W. LaCount, and J. J. Veenhuizen. 1996. Nutrition during the dry period and hepatic lipid metabolism of periparturient dairy cows. J. Dairy Sci. $79: 1850-1864$.

Grummer, R. R. 2008. Nutritional and management strategies for the prevention of fatty liver in dairy cattle. Vet. J. 176:10-20.

Hammon, H. M., G. Stürmer, F. Schneider, A. Tuchscherer, H. Blum, T. Engelhard, A. Genzel, R. Staufenbiel, and W. Kanitz. 2009. Performance and metabolic and endocrine changes with emphasis on glucose metabolism in high-yielding dairy cows with high and low fat content in liver after calving. J. Dairy Sci. 92:1554-1566.

Holness, M. J., and M. C. Sugden. 2003. Regulation of pyruvate dehydrogenase complex activity by reversible phosphorylation. Biochem. Soc. Trans. 31:1143-1151.

Kazantzis, M., and A. Stahl. 2012. Fatty acid transport proteins, implications in physiology and disease. Biochim. Biophys. Acta 1821:852-857.

Kleppe, B. B., R. J. Aiello, R. R. Grummer, and L. E. Armentano. 1988. Triglyceride accumulation and very low density lipoprotein secretion by rat and goat hepatocytes in vitro. J. Dairy Sci. 71:1813-1822.

Koepsell, H., K. Lips, and C. Volk. 2007. Polyspecific organic cation transporters: Structure, function, physiological roles and biopharmaceutical implications. Pharm. Res. 24:1227-1251. 
Leturque, A., E. Brot-Laroche, M. Le Gall, E. Stolarczyk, and V. Tobin. 2005. The role of GLUT2 in dietary sugar handling. J. Physiol. Biochem. 61:529-537.

Loor, J. J., H. M. Dann, R. E. Everts, R. Oliveira, C. A. Green, N. A. Janovick-Guretzky, S. L. Rodriguez-Zas, H. A. Lewin, and J. K. Drackley. 2005. Temporal gene expression profiling of liver from periparturient dairy cows reveals complex adaptive mechanisms in hepatic function. Physiol. Genomics 23:217-226.

Loor, J. J., H. M. Dann, N. A. Janovick-Guretzky, R. E. Everts, R. Oliveira, C. A. Green, N. B. Litherland, S. L. Rodriguez-Zas, H. A. Lewin, and J. K. Drackley. 2006. Plane of nutrition prepartum alters hepatic gene expression and function in dairy cows as assessed by longitudinal transcript and metabolic profiling. Physiol. Genomics 27:29-41.

Loor, J. J., R. E. Everts, M. Bionaz, H. M. Dann, D. E. Morin, R. Oliveira, S. L. Rodriguez-Zas, J. K. Drackley, and H. A. Lewin. 2007. Nutrition-induced ketosis alters metabolic and signaling gene networks in liver of periparturient dairy cows. Physiol. Genomics 32:105-116.

Mach, N., A. A. A. Jacobs, L. Kruijt, J. van Baal, and M. A. Smits, 2011. Alteration of gene expression in mammary gland tissue of dairy cows in response to dietary unsaturated fatty acids. Animal $5: 1217-1230$

Mansbridge, R. J., and J. S. Blake. 1997. Nutritional factors affecting the fatty acid composition of bovine milk. Br. J. Nutr. 78:S37S47.

McNamara, J. P. 1991. Regulation of adipose tissue metabolism in support of lactation. J. Dairy Sci. 74:706-719.

Rakhshandehroo, M., B. Knoch, M. Müller, and S. Kersten. 2010. Peroxisome proliferator-activated receptor alpha target genes. PPAR Res. 2010:1-20.

Ramsay, R. R., and A. Arduini. 1993. The carnitine acyltransferases and their role in modulating acyl-CoA pools. Arch. Biochem. Biophys. 302:307-314.

Ringseis, R., N. Wege, G. Wen, C. Rauer, F. Hirche, H. Kluge, and K. Eder. 2009. Carnitine synthesis and uptake into cells are stimulated by fasting in pigs as a model of nonproliferating species. J. Nutr. Biochem. 20:840-847.

Sanderson, L. M., M. V. Boekschoten, B. Desvergne, M. Müller, and S. Kersten. 2010. Transcriptional profiling reveals divergent roles of PPAR $\alpha$ and PPAR $\beta / \delta$ in regulation of gene expression in mouse liver. Physiol. Genomics 41:42-52.

Schroeder, F., A. D. Petrescu, H. Huang, B. P. Atshaves, A. L. McIntosh, G. G. Martin, H. A. Hostetler, A. Vespa, D. Landrock, K. K Landrock, H. R. Payne, and A. B. Kier. 2008. Role of fatty acid binding proteins and long chain fatty acids in modulating nuclear receptors and gene transcription. Lipids 43:1-17.

Selberg, K. T., C. R. Staples, N. D. Luchini, and L. Badinga. 2005. Dietary trans octadecenoic acids upregulate the liver gene encoding peroxisome proliferator-activated receptor- $\alpha$ in transition dairy cows. J. Dairy Res. 72:107-114.

Sharma, B. K., and R. A. Erdman. 1989. In vitro degradation of choline from selected feedstuffs and choline supplements. J. Dairy Sci. $72: 2772-2776$.

Takahashi, S., T. Tanaka, and J. Sakai. 2007. New therapeutic target for metabolic syndrome: PPARdelta. Endocr. J. 54:347-357.

Takeuchi, K., and K. Reue. 2009. Biochemistry, physiology, and genetics of GPAT, AGPAT, and lipin enzymes in triglyceride synthesis. Am. J. Physiol. Endocrinol. Metab. 296:E1195-E1209.

Thering, B. J., D. E. Graugnard, P. Piantoni, and J. J. Loor. 2009 Adipose tissue lipogenic gene networks due to lipid feeding and milk fat depression in lactating cows. J. Dairy Sci. 92:4290-4300.

van Dorland, H. A., S. Richter, I. Morel, M. G. Doherr, N. Castro, and R. M. Bruckmaier. 2009. Variation in hepatic regulation of metabolism during the dry period and in early lactation in dairy cows. J. Dairy Sci. 92:1924-1940.

Velez, J. C., and S. S. Donkin. 2005. Feed restriction induces pyruvate carboxylase but not phosphoenolpyruvate carboxykinase in dairy cows. J. Dairy Sci. 88:2938-2948.

Walczak, R., and P. Tontonoz. 2002. PPARadigms and PPARadoxes: Expanding roles for PPAR $\gamma$ in the control of lipid metabolism. J Lipid Res. 43:177-186.

Wathes, D. C., Z. Cheng, M. A. Fenwick, R. Fitzpatrick, and J. Patton. 2011. Influence of energy balance on the somatotrophic axis and matrix metalloproteinase expression in the endometrium of the postpartum dairy cow. Reproduction 141:269-281.

Wetterau, J. R., M. C. M. Lin, and H. Jamil. 1997. Microsomal triglyceride transfer protein. Biochim. Biophys. Acta 1345:136-150

Wolfrum, C., C. M. Borrmann, T. Borchers, and F. Spener. 2001 Fatty acids and hypolipidemic drugs regulate peroxisome proliferator-activated receptors alpha- and gamma-mediated gene expression via liver fatty acid binding protein: A signaling path to the nucleus. Proc. Natl. Acad. Sci. USA 98:2323-2328.

Zhao, F.-Q., D. R. Glimm, and J. J. Kennelly. 1993. Distribution of mammalian facilitative glucose transporter messenger RNA in bovine tissues. Int. J. Biochem. 25:1897-1903.

Zom, R. L. G., J. van Baal, R. M. A. Goselink, J. A. Bakker, M. J. de Veth, and A. M. van Vuuren. 2011. Effect of rumen-protected choline on performance, blood metabolites and hepatic triacylglycerols of periparturient dairy cattle. J. Dairy Sci. 94:4016-4027. 